Lucrările Seminarului Geografic Dimitrie Cantemir

Vol. 45, October 2017, pp. 5-14

http://dx.doi.org/10.15551/lsgdc.v45i0.01

\title{
Geodiversity assessment of Moldova catchment in the mountain area
}

\section{Ciprian Chelariu ${ }^{1}$, Oana-Elena Hapciuc ${ }^{1}$}

${ }^{1}$ Alexandru Ioan Cuza University of Iasi, Romania

To cite this article: Chelariu, C. \& Hapciuc, O.-E. (2017). Geodiversity assessment of Moldova catchment in the mountain area. Lucrările Seminarului Geografic Dimitrie Cantemir, Vol. 45, pp. 5-14. DOI: 10.15551/lsgdc.v45i0.01

To link to this article: http://dx.doi.org/10.15551/lsgdc.v45i0.01 


\title{
GEODIVERSITY ASSESSMENT OF MOLDOVA CATCHMENT IN THE MOUNTAIN AREA
}

\author{
Ciprian Chelariu' ${ }^{1}$, Oana-Elena Hapciuc ${ }^{2}$
}

\begin{abstract}
Geodiversity is represented by the uniformity of physical properties of the earth and is considered an important landscape feature in its assessment. Due to the multitude of identified abiotic physical elements (66 elements) in the mountain area of Moldova catchment, the geodiversity index was computed, ranging from 0.30 to 8.72 . The area with the largest number of elements overlaps on Câmpulung Moldovenesc with 12 identified abiotic elements, followed by Pojorâta, Moldova - Sulița, Breaza and Fundu Moldovei with values of the geodiversity index above 2. These localities form a compact area that should be considered in future conservation and promotion strategies.
\end{abstract}

Keywords: geodiversity, GIS, Moldova catchment

\section{Introduction}

The concept of geodiversity is a relatively recent concept, proposed by geologists and geomorphologists, which was first used in the early 1990s as a tool in protected area management to describe the variety from abiotic nature (Gray, 2004; Serrano and RuizFlaño, 2007). Taking into consideration that this concept is recent, a number of additional studies on the importance, spatial distribution, values and potential are needed. The term of geodiversity has emerged as a reaction to the dominance of the term biodiversity, because a large part of the nature conservation field focuses on biotic factors, and this term refers to the preservation of abiotic factors (the non-living parts of natural environment) (Sharples, 2002).

In analyzing the geodiversity of a particular landscape, a number of abiotic natural factors are considered, such as rock types, landforms, hydrograhic network, soils and geomorphological processes. By analyzing these factors and their interactions, the areas with a major geodiversity index can be identified (Manosso and Nóbrega, 2016).

The concept of geodiversity is complex, with an interdisciplinary character and highlights through its approach different points of view. Thus, Sharples (1995) defines geodiversity by the variety of solid rock types, geomorphological characteristics, soil types and the set of systems and processes in a given area.

In 2002, Sharples mentions the distinction between geodiversity, geoconservation and geological heritage:

1 "Al.I.Cuza" University of Iasi, Faculty of Geography and Geology, Department of Geology, Bd.Carol I 20A, 700505, Iasi, Romania, ciprian.chelariu@uaic.ro

"Al.I.Cuza" University of Iasi, Faculty of Geography and Geology, Department of Geography, Bd.Carol I 20A, 700505, Iasi, Romania, oana.hapciuc89@gmail.com 
- geodiversity is represented by the quality that needs conservation;

- geoconserving is the effort made for conservation;

- geological heritage includes concrete examples identified as having a significance for conservation. Thus, these terms are inseparable for geoconserving an area, being in interdependence with each other.

In 2001, Stanley defines geodiversity as the link between people, landscape and culture through interactions between biodiversity with soils, minerals, rocks, fossils, active processes and the formed environment.

Gray (2004) considers geodiversity as a natural distribution of geology (including rocks, minerals and fossils), soil charateristics, landforms and geomorphological processes, as well as the interactions between them. Another approach of geodiversity is proposed by Kozlowski (2004), that in addition to abiotic factors includes both endogenous and exogenous natural processes and human activity.

Serrano and Ruiz-Flaño (2007) propose a broader concept from a spatial analysis perspective, using geodiversity to define the abiotic natural diversity of the tectonic, geomorphologic, edaphic, hydrological, topographic and lithological elements.

For the theoretical, quantitative assessment of geodiversity and its mapping, a number of studies have been made, that contributed in this field: Sharples (1995, 2002), Gray (2004), Benito-Calvo et al. (2009), Jačková and Romportl (2012), Silva et al. (2013), Pereira et al. (2013), but standardized methods for geodiversity assessment have not yet been established.

At national level, there are relatively few studies regarding the geodiversity and its evaluation, these mostly targeting Hunedoara and Buzău counties: Otiman P.I. (2009), Comănescu and Nedelea (2012), Melinte-Dobrinescu et al. (2016), but also other areas such as The Aninei Mountains (Popa et al., 2010), Gutâi Mountains (Kovacs and Fülöp, 2009) and the area of Rarău Mountains (Turculeț and Țibuleac, 2009).

For the areas with a high degree of geodiversity, biodiversity and cultural diveristy, geoparks can be set up. The geopark is a territory that integrates geological heritage elements into the territorial development strategies supported by various European programs (Global Geoparks Network, 2001).

In Romania, even if there are a large number of geological and paleontological sites of major importance, only two geoparks are found within the European Geoparks Network: Hațeg Country Dinosaurus Geopark and Mehedinţi Plateau Geopark. Other initiatives to designate some geopark areas are in the project phase: Anina Geopark (2007 local project) and Buzau Geopark that already has a proposal for a development strategy (Stoleriu, 2014).

This study evaluates the degree of geodiversity of the upper catchment of Moldova and the possibility of proposing the establishment of a geopark.

\section{Study area}

The catchment of Moldova river is located in the northern part of Romania and has an area of drainage basin of $4299 \mathrm{~km}^{2}$. Moldova River is the second right tributary of Siret River, with a main course length of $213 \mathrm{~km}$ and crosses from NW to SE the carpathian unit with the subunits of the crystalline mountains and flysch, the subcarpathian unit and the plateau unit.

The area analyzed in this study corresponds to the mountain area of Moldova catchment (Figure 1) with a surface of $2488 \mathrm{~km}^{2}$ and with a folded and fractured structure of 
hard rocks (metamorphic rocks) and rocks characteristic to carpathian flysch. The river crosses diagonally the relief units from the mountain area, between Lucina peak (1588 m) and Gura Humorului $(480 \mathrm{~m})$ and overlaps the crystalline-mesozoic unit formed by crystalline shale, quartz, crystalline limestone and the flysch unit formed by sandstone intervals, limestomes, conglomerates, marls and clays. (Chiriloaei et al., 2012).

The crystalline-mesozoic area crossed by Moldova River corresponds to Obcina Mesticănişului (at the extremity of which there are the springs of the river), a unit with an average altitude of $1150 \mathrm{~m}$, which differs from the flysch area through a pronounced massivity (Barbu, 1976) and goes up to Rarău and Giumalău.

Most of Moldova catchment (about 80\%) overlaps the carpathian flysch area (Chiriloaei, 2012). The main subunits drained by Moldova River in the flysch area are Obcina Feredeului (forming the watershed between Moldovița and Moldova River), the western slope of Obcina Mare with the southern extensions formed by Obcina Cacica (Amăriucăi, 2000).

The carpathian sector of Moldova's catchment is symmetrical and accounts $43 \%$ of the total area (Negrea G.Z. and Brânzilă M., 2005). In this sector, Moldova recieves tributaries with appeciable flows from both the left (Sadova, Moldovița, Humor) and the right side (Putna, Suha, Voroneț).

In the upper course of the basin, in the area of transerval valleys, a specific landscape was formed, which is represented by canyons, as Moldova's at Breaza or Lucava's and Tătărcăi's, isolated large cliffs, such as Adam and Eva from Pojorâta or through a landscape of pyramids and towers, vertical walls and rocks and scree clusters, such as Pietrele Doamnei (Brânduș and Grasu, 1991), as well as a series of surface and depth karstic forms (the Liliecilor Cave).

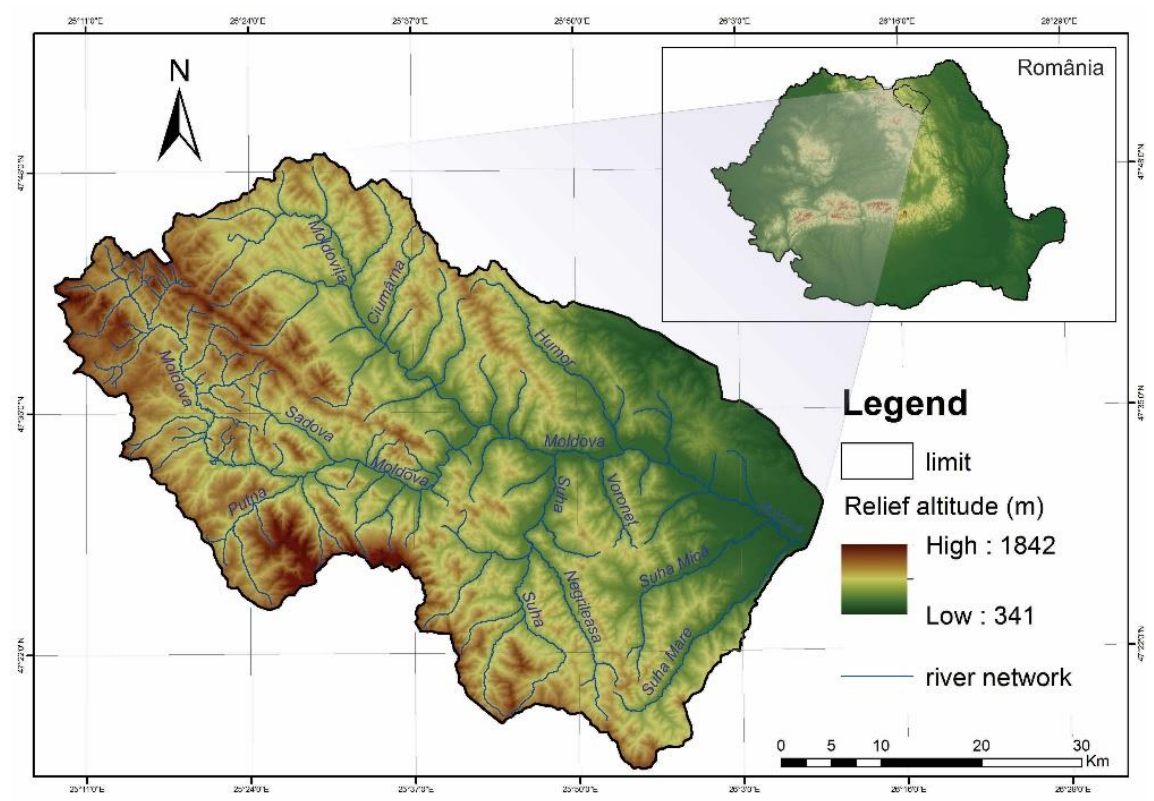

Figure 1: Geographical location of the study area 
From an administrative point of view, the study area overlaps totally over Suceava County, respectively over 28 localities within it (Figure 2).

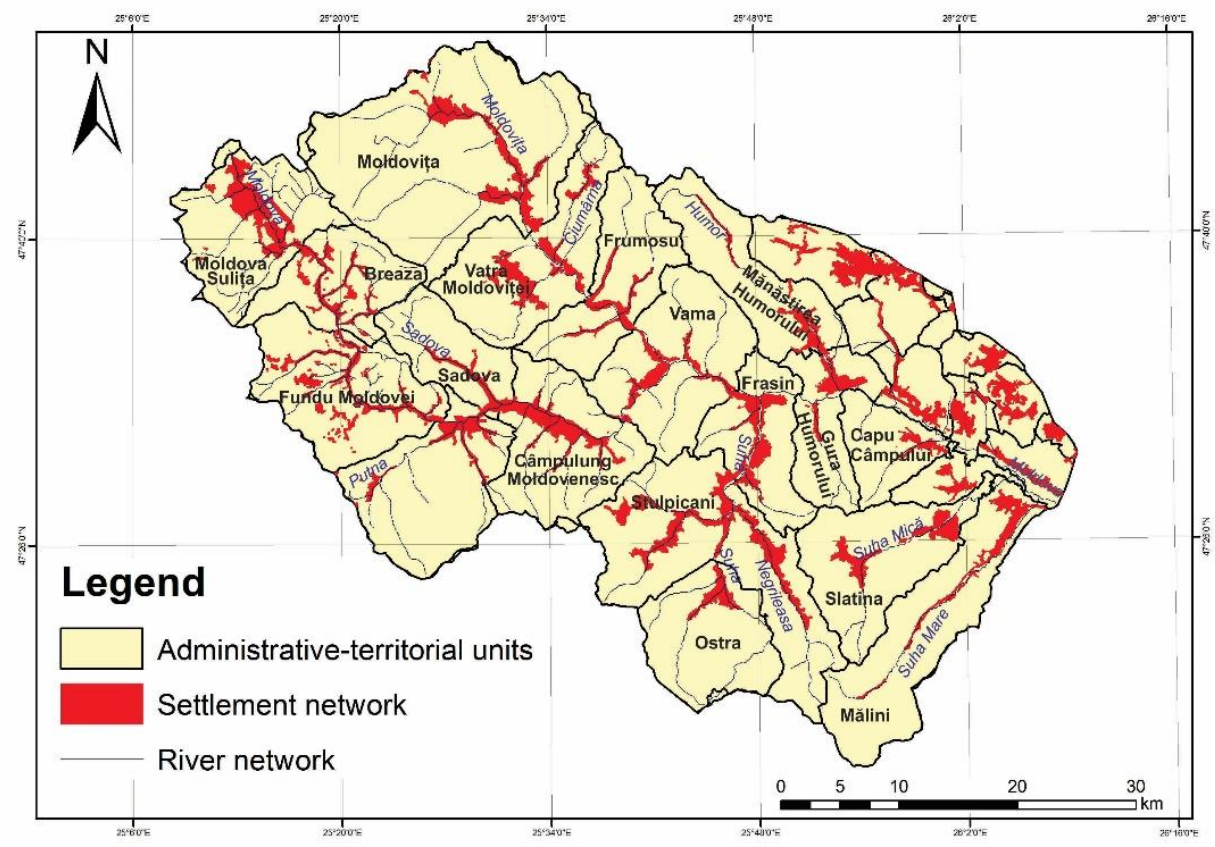

Figure 2: Administrative-territorial units of the study area

In the present study, the settlements were also taken into consideration because, in the case of proposing a geopark, besides the geological and geomorphological aspects are analyzed the economic and cultural ones too (Cimermanová, 2010).

\section{Methodology}

The geodiversity assessment was based on the methodology proposed by Serrano and Ruiz-Flano (2007) with some changes dictated by local conditions.

This methodology has been applied to the upper and middle basin of Moldova River.

In calculating the geodiversity index (Gd) determined using equation (1), the geological, geomporphological and hydrological elements identified for each administrativeterritorial unit were taken into account.

\section{Gd = Eg R / Ln S}

where:

- $G d$ is Geodiversity Index;

- $E g-$ number of different physical elements in the unit;

- $R$ - coefficient of roughness of the unit;

- $S$-surface of the unit, in $\mathrm{km}^{2}$. 
Identification of the abiotic elements was achieved both by consulting the specialized literature and by field stages.

The roughness coefficient $(\mathrm{R})$ was estimated taking into account the land slopes (Figure 3) for each administrative-territorial unit, depending on the predominant slope interval (Table 1). If two or more dominant slope intervals were characteristic for an administrativeterritorial unit, the value of the roughness index was calculated proportional to the area occupied by each interval.

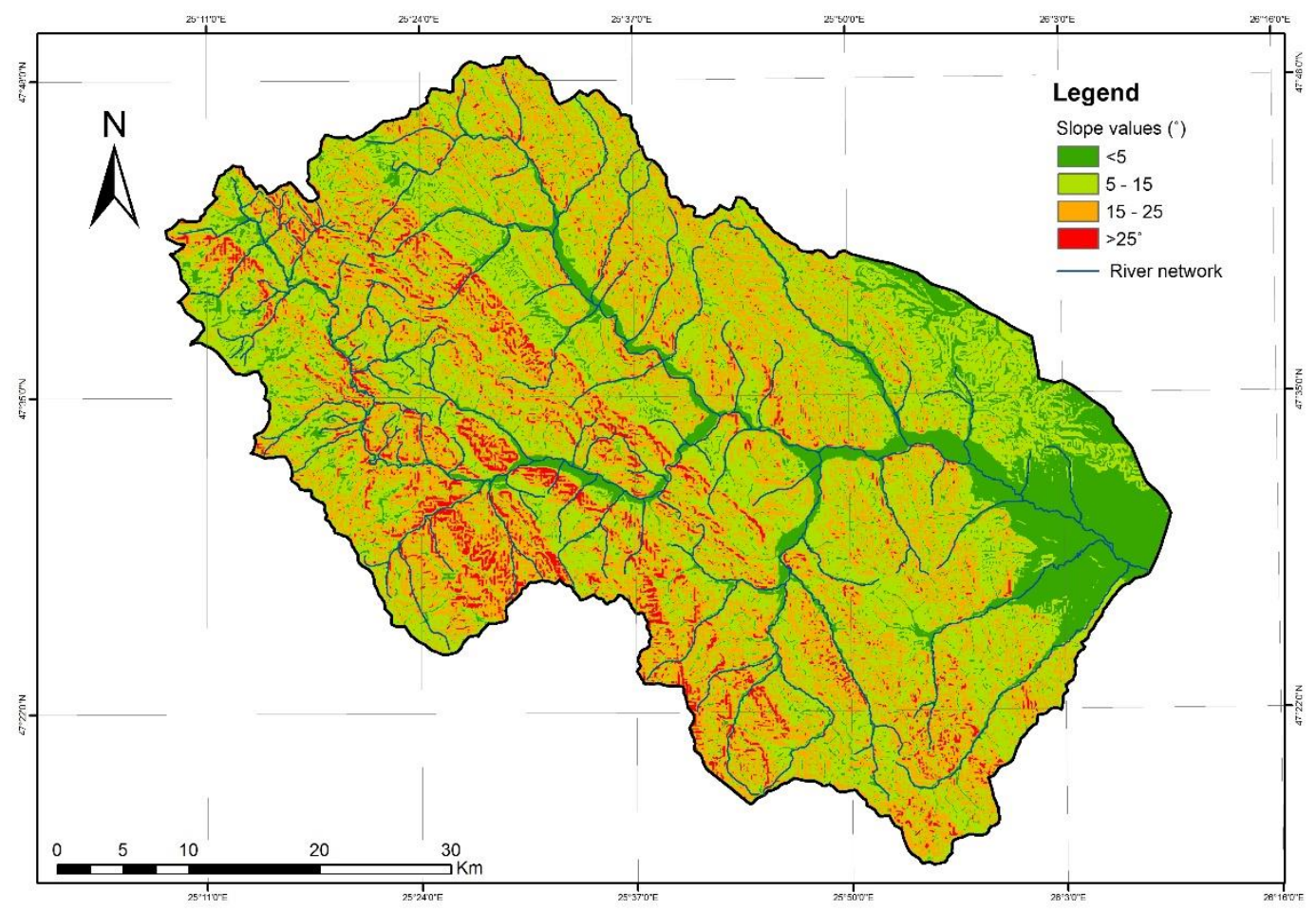

Figure 3: Distribution of slope values

Table 1. Roughness values according to the slope classes (after Serrano et al., 2009)

\begin{tabular}{|c|c|c|c|c|}
\hline $\begin{array}{c}\text { Roughness } \\
\text { values }\end{array}$ & 1 & 2 & 3 & 4 \\
\hline Slopes $^{\circ}$ & $0-5$ & $6-15$ & $16-25$ & $26-50$ \\
\hline
\end{tabular}

Data processing and final result spatialization was performed using the spatial analysis program, ArcGis (ESRI, Redlands, CA, USA).

\section{Results and discussions}

From a territorial point of view, the studied area is unfolded on the surface of 26 localities, including 1 municipality, 2 towns and 23 communes. For the communes whose surface area did not fully fall within the perimeter of the studied hydrographic basin, only the 
surface that overlaps the study area was taken into account in the calculation of the geodiversity index.

After applying the calculation algorithm, the administrative-territorial units were grouped into four geodiversity classes (Figure 4): 0.3-0.7 - low geodiversity, 0.71-1.00 medium geodiversity, 1.01-1.50 - high geodiversity and $>1.51$ - very high geodiversity.

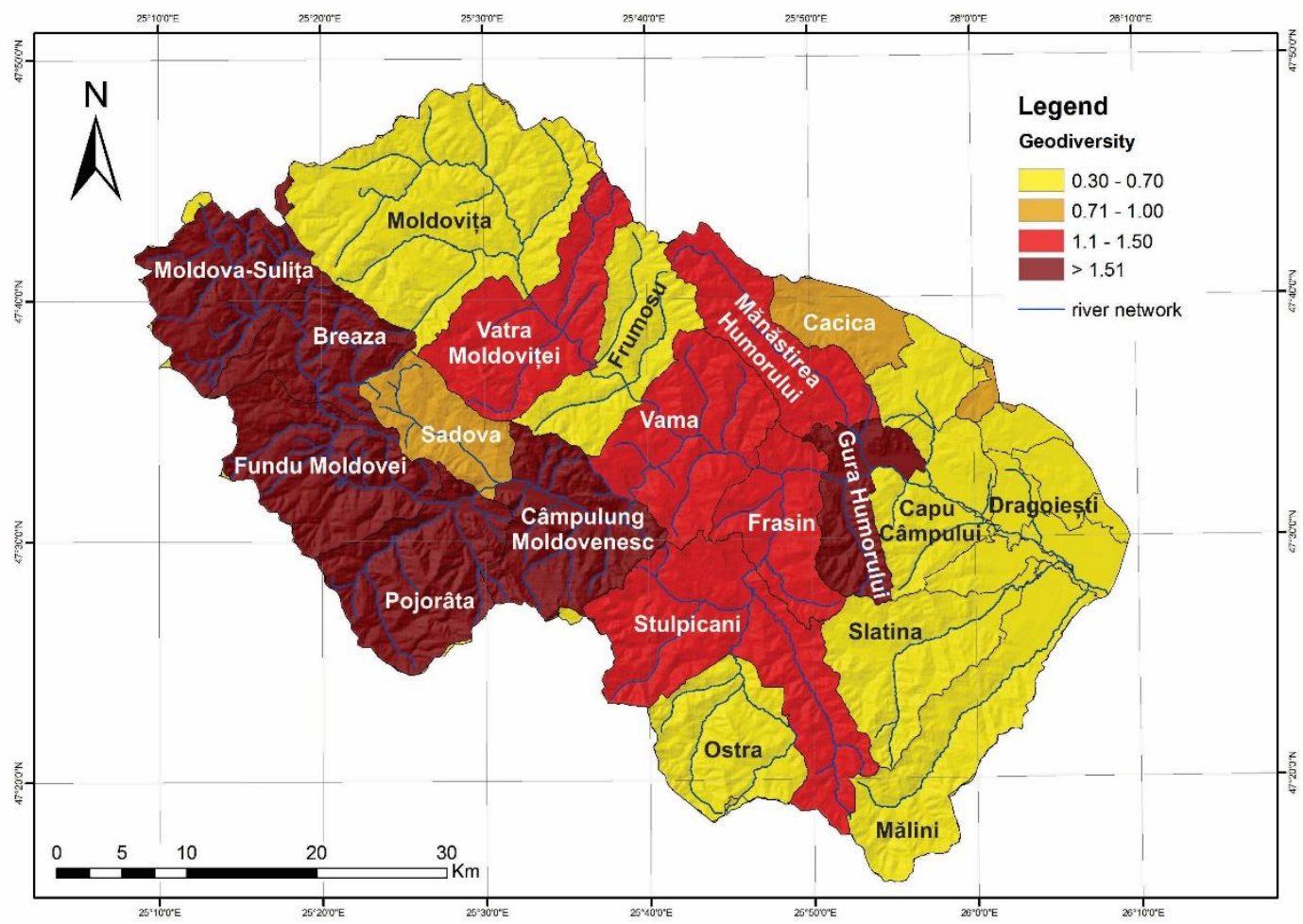

Figure 4: Geodiversity map of the study area

As can be seen, the highest values of the geodiversity index characterize the upstream area within the catchment, located in the north-east. Thus, the localities that have high values of the geodiversity index are Câmpulung Moldovenesc, Pojorâta, Fundu Moldovei, Breaza and Moldova-Sulița (Table 2). They form a compact area that overlaps the southern side of Obcina Feredeului and the northern side of Obcina Mestecăniş, as well as an important area within Rarău and Giumalău Mountains. High values are influenced by the number of abiotic elements identified in these areas and by the values of the roughness coefficient determined by the slope values. Within the Moldava catchment, the slope values follow the distribution model of the altitudinal steps, being higher in the north-west and more modest in the southeastern part. 
Table 2: The geodiversity index obtained for each administrative-territorial unit from the study area

\begin{tabular}{|c|c|c|}
\hline Municipality & Surface $\left(\mathbf{k m}^{2}\right)$ & $\begin{array}{c}\text { Geodiversity } \\
\text { value }\end{array}$ \\
\hline Câmpulung Moldovenesc & 123,47 & 8,72 \\
\hline Gura Humorului & 70,46 & 1,76 \\
\hline Frasin & 83,59 & 1,13 \\
\hline Breaza & 84,28 & 2,26 \\
\hline Berchișești & 19,06 & 0,51 \\
\hline Cacica & 67,55 & 0,71 \\
\hline Cornu Luncii & 28,26 & 0,30 \\
\hline Capu Câmpului & 52,84 & 0,50 \\
\hline Dragoiești & 25,73 & 0,46 \\
\hline Ciprian Porumbescu & 17,52 & 0,52 \\
\hline Frumosu & 104,22 & 0,54 \\
\hline Fundu Moldovei & 137,37 & 2,03 \\
\hline Horodniceni & 6,13 & 0,55 \\
\hline Mălini & 147,58 & 0,40 \\
\hline Mănăstirea Humorului & 98,77 & 1,09 \\
\hline Moldova-Sulița & 121,88 & 3,64 \\
\hline Moldovița & 291,57 & 0,53 \\
\hline Ostra & 102,56 & 0,65 \\
\hline Păltinoasa & 36,27 & 0,56 \\
\hline Pârteștii de Jos & 44,76 & 0,53 \\
\hline Pojorâta & 132,40 & 5,73 \\
\hline Sadova & 67,16 & 0,95 \\
\hline Stulpicani & 201,29 & 1,13 \\
\hline Valea Moldovei & 26,50 & 0,46 \\
\hline Vama & 135,99 & 1,22 \\
\hline Vatra Moldoviței & 135,40 & 1,22 \\
\hline
\end{tabular}

The most important abiotic elements identified within the studied area are summarized in Table 3. Some of these are already included in different categories of areas or natural monuments protected by national legislation.

Table 3: Valuable elements form the Moldova catchment

\begin{tabular}{|c|c|}
\hline Administrative unit & Geodiversity objectives \\
\hline Câmpulung Moldovenesc & Pietrele Doamnei (Rarău) \\
& Moara Dracului Canyon \\
& Piatra Buhei \\
Liliecilor Cave (Rarău) \\
\hline Gura Humorului & Piatra Pinului \\
& Piatra Șoimului \\
\hline Frasin & The sandstone pothole from Frasin \\
\hline Fundu Moldovei & Triassic Klippa on the Cailor Creek \\
\hline Moldova-Sulița & Lucavei Canyon \\
\hline Pojorâta & Formation with Aptychus from Pojorâta \\
\hline
\end{tabular}


In contrast, the localities with low values of the geodiversity index overlap mainly over the contact area between the mountain area and the plateau. Also, the area crossed by Moldovița River, a left tributary of Moldova, presents low values of the geodiversity index. Thus, this index presents low values that are influenced by the geological substrate, low slopes and the large area of the administrative-territorial units (eg: Moldovița commune).

\section{Conclusions}

Geodiversity is a relatively new concept used in protected areas management. This concept involves identifying abiotic elements in a given area.

Several studies have been developed to assess geodiversity, but standardized methods have not yet been established.

At national level, most of the studies were mainly focused on the areas of "Țara Hațegului" Geopark and the region "Ținutul Buzăului".

In order to expand this type of analysis, the present study identifies the geodiversity potential for the mountain sector of the Moldova River catchment, located in the northern part of the Eastern Carpathians.

The analysis was carried out at the level of administrative-territorial unit and a number of 66 abiotic elements, unequally distributed, were identified. By calculating the geodiversity index, a compact area with a high geodiversity potential was located in the southwestern part of the studied area. This area may be the subject for more complex in-depth studies, which in addition to geodiversity should include biodiversity and cultural heritage to identify the possibility of proposing a geopark.

\section{References}

1. Amăriucăi M., 2000. Șesul Moldovei extracarpatice dintre Păltinoasa și Roman. Studiu geomorfologic și hidrologic, Editura Corson, Iași.

2. Barbu N., 1976. Obcinele Bucovinei, Editura Științifică și Pedagogică, București.

3. Benito-Calvo A., Perez-Gonzalez A., Magri O., Meza P., 2009. Assessing regional geodiversiy: The Iberian Peninsula, Earth Surface Processes and Landforsm, 34(10), 1433 - 1445.

4. Brânduș C., Grasu C., 1991. Valea Moldovei, Editura pentru Turism, București.

5. Cimermanová I., 2010. Geoparks in Slovakia, Acta Geoturistica, 1(2), 34 - 40.

6. Chiriloaei F., Rădoane M., Perșoiu I., Popa I., 2012. Late Holocene history of the Moldova River Valley, Romania, Catena, 93, $64-77$.

7. Chiriloaei F.A., 2012. Analiza cantitativă a modificărilor albiei râului Moldova în sectorul extracarpatic, Teză de doctorat, Universitatea "Alexandru Ioan Cuza" din Iași.

8. Comănescu L., Nedelea A., 2012. The assessment of geodiversity - a premise for declaring the geopark Buzăului county (Romania), Journal of Earth System Science, 6(121), 1493 - 1500.

9. Gray M., 2004. Geodiversity valuing and conserving abiotic nature, John Wiley \& Sons, Ltd, Queen Mary, University of London.

10. Jačková K., Romportl D., 2012. The relationship between geodiversity and habitat richness in Šumava National Park and Krivoklátsko PLA (Czech Republic): A Quantitative Analysis Approach, Journal of Landscape Ecology, 1(1), 23 - 38.

11. Kovacs M., FülőpA., 2009. Baia Mare Geologica land Mining Park - a potential new Geopark in the northwestern part of Romania, Studia Universitas Babes-Bolyai, Geologia 54(1), 27 - 32.

12. Kozlowski S., 2004. Geodiversity. The concept and scope of geodiversity. Przeglad Geologiczny, $52(8 / 2) 833-837$. 
13. Manosso F.C., Nóbrega M.T., 2016. Calculation of Geodiversity from Landscape Units of the Cadeado Range Region in Paraná, Brazil, Geoheritage, 8, 189 - 199.

14. Melinte-Dobrinescu A., Brustur T., Jipa D., Macaleț R., Ion G., Popa A., Stănescu I., Briceag A., 2016. The Geological and Palaeontological Heritage of the Buzău Land Geopark (Catpathians, Romania), Geoheritage.

15. Negrea G.Z., Brânzilă M., 2005. Rezervațiile natural din bazinul vâii Moldovei. Aspecte științifice și metodice, Editura Universității ”Alexandru Ioan Cuza” din Iași.

16. Otiman P.I., 2009. Bio and geodiversity conservation as support to sustainable development and economic and social growth in the area Hațeg-Retezat, Agricultural Economics and Rural Development, 1, 3 - 18 .

17. Popa M., Kedzior A., Fodolică V., 2010. The Anina Geopark: Preserving the geological heritage of the South Carpathians, Rev. Roum. Geologie, 109 - 113.

18. Serrano E., Ruiz-Flaño P., 2007. Geodiversity. A theoretical and applied concept, Geographica Helvetica, 62, $140-147$.

19. Serrano E., Ruiz- Flaño P., Arroyo P., 2009. Geodiversity assessment in a rural landscape: TiermesCaracena area (Soria, Spain), Memorie Descrittive della Carta Geologica d'Italia., 87, 173 - 180.

20. Silva J., Pereira D., Aguiar A., Cleide R., 2013. Geodiversity assessment of the Xingu drainage basin, Journal of Maps, 9(20), $254-262$.

21. Sharples C., 1995. Geoconservation in forest management: principles and procedures, Tasforest, 7 , $37-50$.

22. Sharples C., 2002. Concepts and Principles of Geoconservation, Tasmanian Parks \& Wildlife Service website, $79 \mathrm{p}$.

23. Stanley M., 2001. Geodiversity Update, 1, 1.

24. Stoleriu O.M., 2014. Nstional approaches to geotourism and geoparks in Romania, $14^{\text {th }}$ International Multidisciplinary Scientific GeoConference (SGEM), Ecology and Environmental Protection,.

25. Pereira D.I., Pereira P., Brihla J., Santos L., 2013. Geodiversity assessment of Paraná State (Brazil): An innovative approach, Environmental Management, 52, 541 - 552.

26. Turculeț I., Țibuleac P., 2009. New proposals for protected natural areas in the Rarău syncline (Eastern Carpathians, Romania). II. Triasic, Analele Știinţifice ale Universității ”Alexandru Ioan Cuza" Iași, Geologie, LV(2), 53 - 60.

27. http://www.europeangeoparks.org 
